"Przegląd Prawa Konstytucyjnego"

Nr $4(16) / 2013$

\title{
Recenzja
}

\section{Bogusław Banaszak, Michał Bednarczyk, Aktywizm sędziowski we wspótczesnym państwie demokratycznym, Wydawnictwo Sejmowe, Warszawa 2012, ss. 282}

Monografia Aktywizm Sędziowski we współczesnym państwie demokratycznym stanowi kontynuację komparatystycznych badań naukowych w zakresie prawa konstytucyjnego autorów, w szczególności profesora Bogusława Banaszaka. Stanowi ona pogłębioną analizę w ujęciu teoretycznym, historycznym i komparatystycznym szczególnego zjawiska, jakim jest aktywizm sędziowski. Poruszone w opracowaniu zagadnienie nie stanowi novum w badaniach konstytucjonalistów i teoretyków prawa zarówno w Polsce, jak i zagranicą. Na polskim rynku wydawniczym nie ma żadnego opracowania naukowego, w którym autor (autorzy) próbowałby kompleksowo odnieść się do powyższej problematyki, scharakteryzować zjawiska aktywizmu oraz pasywizmu sędziowskiego i jeszcze dodatkowo dokonać porównania różnych systemów prawnych. W świetle powyższego już same założenia i cele autorów godne są uwagi i zainteresowania.

Zasadniczym celem autorów monografii było sformułowanie w miarę uniwersalnej definicji zjawiska aktywizmu sędziowskiego, przedstawienie działalności orzeczniczej czterech organów kontroli konstytucyjności prawa w różnych państwach oraz odniesienie ich rozstrzygnięć do elementów skonstruowanej przez siebie definicji aktywizmu sędziowskiego. Ostatecznie autorzy sformułowali wnioski, w których wskazali, które sądy konstytucyjne spełniają wyróżnione przez nich przesłanki bycia sądami aktywistycznymi, a których działalność orzecznicza charakteryzuje się znamionami pasywizmu. Bogusław Banaszak i Michał Bednarczyk dla poparcia swoich wniosków i spostrzeżeń posłużyli się bardzo bogatym orzecznictwem wszystkich 
sądów konstytucyjnych, których działalność została poddana analizie. Równocześnie w szerokim zakresie wykorzystali literaturę zarówno o charakterze naukowym, jak również publicystycznym, która została wydana w poszczególnych państwach. Dzięki temu czytelnik uzyskuje obraz poglądów prezentowanych $\mathrm{w}$ doktrynach prawa i w mediach w analizowanych systemach. Umożliwia to czytelnikowi wyrobienie sobie indywidualnego poglądu, a ocenom autorów nadaje cechy obiektywizmu, uniwersalności i wszechstronności.

Opracowanie zasadniczo można podzielić na dwie części. W pierwszej autorzy definiują zjawisko aktywizmu sędziowskiego, przedstawiają genezę i etymologię tego pojęcia (por. rozdział I). Ponadto wymieniają cechy, którymi musi się charakteryzować działalność sędziów, by uznać ją za aktywistyczną (por. s. 28, 31, 32, 46). W drugiej części Bogusław Banaszak oraz Michał Bednarczyk przedstawiają działalność 4 sądów konstytucyjnych (Sądu Najwyższego w Stanach Zjednoczonych, Trybunału Konstytucyjnego w Austrii, Federalnego Trybunału Konstytucyjnego w Republice Federalnej Niemiec oraz Trybunału Konstytucyjnego w Polsce). Tę część pracy również można podzielić na dwa segmenty. W pierwszym autorzy przedstawiają aktywizm sędziowski w państwach common law, w szczególności w USA, a w drugim w państwach opartych na kulturze rzymskiej (kontynentalnej) w Austrii, Niemczech i Polsce.

Mimo faktu, że autorzy podjęli temat, który wielokrotnie analizowany był i jest w nauce prawa, postawili oni sobie arcytrudne zadanie. Sformułowanie uniwersalnej definicji i wyłonienie cech wspólnych charakterystycznych dla aktywizmu sędziowskiego występującego w różnych porządkach prawnych jest w mojej ocenie zadaniem bardzo trudnym lub prawie niemożliwym. Niewątpliwie we wszystkich omówionych przez autorów państwach pojawia się problem aktywizmu sędziowskiego jako przedmiot badań nauk prawnych oraz w publicystyce medialnej. Trudność metodologiczna badania tego zjawiska w różnych systemach polega na tym, że w poszczególnych krajach ma ono różne podłoże genetyczne, społeczne, polityczne i prawne. W omówionych państwach sądy konstytucyjne działają w oparciu o bardzo różniące się akty normatywne, które inaczej definiują ich kompetencje, zadania, procedury postępowania, formy działalności, typy i skutki orzeczeń, funkcje itp. Ponadto zjawisko aktywizmu sędziowskiego wykształ- 
ciło się $\mathrm{w}$ różnych systemach i kulturach prawnych oraz dotyczy różnych organów i niejednolitych modeli kontroli konstytucyjności prawa, czasem gruntownie się różniących. W jednym porządku prawnym określone działania, orzeczenia sądu konstytucyjnego, będą znajdowały podstawy prawne, a w innym takie same działanie podejmowane mogą być bez jasno sformułowanych kompetencji w regulacjach prawnych. W konsekwencji, to co w jednym państwie może być uznane za aktywizm, w drugim będzie traktowane jako zwyczajne wykonywanie kompetencji, a w trzecim państwie może to samo orzeczenie być postrzegane jako przejaw powściągliwości sędziowskiej (pasywizmu). Pragnę wskazać, iż przedstawione przeze mnie wątpliwości nie dyskwalifikują w żadnej mierze opracowania ani jego koncepcji, stanowią one raczej dodatkowy jego atut, albowiem świadczą o tym, że autorzy podjęli się zadania niebanalnego o dużym ciężarze merytorycznym i metodologicznym.

W pierwszym rozdziale autorzy wymienili przesłanki, które musi spełniać działalność orzecznicza sądu konstytucyjnego, by uznać go za aktywistyczny. Wskazują oni, iż zjawisko to powinno charakteryzować się następującymi cechami: rozstrzygnięcie stanowi efekt ważenia argumentów, które dotyczą niejednoznacznej normy prawnej; rozstrzygnięcie wyklucza domniemanie poprawności ocen, legalności oraz celowości działania prawodawcy; rozstrzygnięcie dotyczy sprawy o dużej doniosłości społecznej; może ono przełamywać dotychczasową linię orzeczniczą (s. 45-46). Istotą aktywności sądu jest ocena sposobu interpretacji Konstytucji (s. 31). Autorzy w znacznej mierze nie biorą pod uwagę relacji zachodzących pomiędzy podstawami prawnymi działalności sądów konstytucyjnych, które określają m.in. skutki ich orzeczeń oraz samymi rozstrzygnięciami tych organów i ich konsekwencjami. Abstrahując od porządków prawnych USA, Austrii i RFN, mam w powyższej materii pewne spostrzeżenia. Po pierwsze, definicja aktywizmu sędziowskiego (cechy uniwersalne) odbiega w poważnej mierze od przyjętego rozumienia tego pojęcia w polskiej nauce i publicystyce. Aktywizm polskiego Trybunału Konstytucyjnego rozumiem przede wszystkim jako działalność orzeczniczą tego organu, w której wychodzi on poza swoje przewidziane prawem kompetencje, w szczególności sam definiuje skutki prawne swoich rozstrzygnięć, tworzy nowe, nieprzewidziane w przepisach ustawy zasadniczej formuły sentencji, wychodzi poza językowe zna- 
czenie przepisów konstytucji i ustaw, tworzy nowe dotychczas nieistniejące w porządku prawnym normy prawne. Równocześnie nie podzielam stanowiska autorów, iż aktywizm sędziowski wywołuje poważne spory w nauce i społeczeństwie oraz skutkuje krytyką aktywistycznego orzecznictwa dokonywaną przez inne organy władzy publicznej. Powyższe konsekwencje wywoływane są bowiem przez wszystkie lub przez prawie wszystkie rozstrzygnięcia Trybunału Konstytucyjnego, nie tylko przez te orzeczenia, które wydane zostały w ramach szeroko rozumianego aktywizmu sędziowskiego. Postępowanie przed TK ma charakter kontradyktoryjny (sporny). Siłą rzeczy implikuje to uczestnictwo w procesie dwóch stron; jednej zainteresowanej uchyleniem w jej ocenie niekonstytucyjnej normy, i prawodawcy, który utrzymuje, że ustanowiona przez niego norma nie jest wadliwa. Taka formuła procedowania zawsze musi skończyć się rozstrzygnięciem, w którym jedna strona zostanie usatysfakcjonowana przy równoczesnym oddaleniu żądań drugiej strony. W konsekwencji nieuniknionym elementem rozstrzygnięcia będzie jego krytyka przez stronę, której wnioski nie zostały przez TK uwzględnione. Spór ten przenosi się na opinię publiczną, której ocena rozstrzygnięcia opiera się na preferencjach politycznych i na udzielonym poparciu dla jednej z uczestniczących stron. Konflikt ten i krytyka orzeczeń są nieuchronne i immanente.

Autorzy monografii wskazali, że w przeważającej mierze aktywizm sędziowski traktowany jest w publicystyce i nauce jako zjawisko pejoratywne (s. 8-9, 42). Należy zgodzić się ze stwierdzeniem, że w mediach ugruntowało się przekonanie, iż sąd aktywny „nie zasługuje na uznanie” (s. 9), a samo zjawisko aktywizmu sędziowskiego ma charakter pejoratywny. Jest to skutkiem niezrozumienia omawianego problemu, jego powierzchownej analizy i oceny orzeczeń przez pryzmat politycznych, a nie prawnych uwarunkowań. Równocześnie mam pewne wątpliwości, czy w nauce prawa, w szczególności polskiego, zjawisko aktywizmu sędziowskiego jest generalnie negatywnie oceniane. Zgadzam się, iż orzeczenia uznane przez autorów za aktywistyczne poddawane są pewnej krytyce w doktrynie prawa, jednakże owa krytyka wcale nie jest poważniejsza niż ma to miejsce w przypadku pozostałych rozstrzygnięć Trybunału Konstytucyjnego. Krytyka w przeważającej mierze nie dotyczy aktywizmu, tylko istoty i motywów rozstrzygnięcia. W mojej ocenie w polskiej nauce pojęcie aktywizmu sędziowskiego jest wyko- 
rzystywane dla zamaskowania (ukrycia) quasi-normodawczej działalności polskiego sądu konstytucyjnego. Autorzy różnych publikacji naukowych nie chcąc wprost przyrównywać Trybunału do prawodawcy pozytywnego, nazywając jego działalność aktywizmem sędziowskim. Jest to zabieg językowy, który umożliwia uniknięcie budzącego bardzo duże kontrowersje w nauce polskiego prawa przypisania sądowi konstytucyjnemu funkcji prawodawczej1. Podsumowując, autorzy w swojej pracy przypisali pojęciu „aktywizm sędziowski" trochę inne znaczenie niż posiada ono w polskim prawoznawstwie. Faktu tego nie należy bynajmniej traktować jako wady opracowania. Świadczy on o kreatywnym podejściu autorów do poruszonego zagadnienia, poszukiwaniu przez nich nowych koncepcji oraz ich otwarciu na komparatystykę prawno-konstytucyjną. Ponadto, u podstawy definicji przyjętej przez twórców legły założenia metodologiczne, które w zasadniczej mierze abstrahowały od konieczności przeprowadzania analiz porządków wewnętrznych i skupiały się na szukaniu cech wspólnych dla działalności orzeczniczej sądów konstytucyjnych w różnych państwach i systemach.

Bogusław Banaszak oraz Michał Bednarczyk swoje tezy popierają licznymi przykładami orzeczeń wydanych przez sądy konstytucyjne. Mają one zobrazować czytelnikowi zjawisko aktywizmu sędziowskiego oraz ułatwić zrozumienie tego problemu. Autorzy podając przykłady aktywizmu sędziowskiego w poszczególnych państwach, odwołują się do różnego rodzaju praktyk orzeczniczych sądów konstytucyjnych. W Stanach Zjednoczonych jako przejaw aktywizmu traktowane jest przede wszystkim wykształcenie się systemu judical review i dokonywanie w jego ramach kontroli konstytucyjności aktów normatywnych. W Austrii jako przykłady aktywizmu Trybunału Konstytucyjnego autorzy wskazują w szczególności: podejmowanie nowych problemów, szukanie nowych sformułowań, metod wykładni (s. 155-157). W Republice Federalnej Niemiec przejawem aktywizmu jest wykształcenie się tzw. wyroków interpretacyjnych, uchylanie aktów normatywnych parlamentu i poszukiwanie (rozszerzanie) kompetencji (odpowiednio: s. 170,176 i 177).

Przedstawione przez autorów rozstrzygnięcia sądów konstytucyjnych wypełniają przesłanki sformułowanej w I rozdziale ogólnej definicji akty-

1 Podobnie rzecz się ma z pojęciem tzw. wykładni twórczej. 
wizmu sędziowskiego. Orzeczenia te posiadają wyróżnione przez autorów cechy, które umożliwiają zaliczenie ich do jednej kategorii. Równocześnie symptomatyczny jest brak więzi merytorycznych (wspólnych elementów treściowych) i formalnych (procesowych) pomiędzy przedstawionymi rozstrzygnięciami. Zasadniczo różne przejawy działalności judykacyjnej sądów konstytucyjnych w poszczególnych państwach traktowane są jako przejawy aktywizmu sędziowskiego. Wskazane przykłady tego zjawiska z poszczególnych państw dotyczą różnych kwestii i zagadnień oraz zostały wydane w oparciu o różne podstawy ustrojowe, procesowe i kompetencyjne. W konsekwencji trudno jest na pierwszy rzut oka zrekonstruować powiązania pomiędzy tymi rozstrzygnięciami, które wynikają z faktu, iż są one przejawem aktywizmu sędziowskiego. Dopiero analiza całego opracowania, ze szczególnym uwzględnieniem I rozdziału, umożliwia odszukanie tych powiązań. Jest to skutkiem m.in. faktu odrębności ustrojowo-kulturowych pomiędzy poszczególnymi państwami, o których była już wcześniej mowa. Prowadzi to do powstania pewnej konfuzji, jakie rodzaje orzeczeń są przejawem aktywizmu i dlaczego. W ostatecznym rozrachunku należy stwierdzić, iż dla autorów drugoplanowe znaczenie miała sama merytoryczna treść rozstrzygnięć, skupiali się oni przede wszystkim na problemie, czy działalność sądów konstytucyjnych w poszczególnych państwach wypełnia kryteria aktywizmu sędziowskiego, które sformułowano w I rozdziale pracy.

Autorzy skonstruowali definicję aktywizmu sędziowskiego z pominięciem prawnych, w szczególności formalnych, ustrojowych i kompetencyjnych podstaw działalności poszczególnych sądów konstytucyjnych. W rozdziałach dotyczących poszczególnych sądów konstytucyjnych przedstawione zostały co prawda podstawy prawne działalności tych organów i ich kompetencje. Jednakże elementy te pozostają w oderwaniu od zasadniczych rozważań i argumentów autorów. Stanowią one raczej uzupełnienie wywodu niż jego punkt wyjścia. Był to umyślny zabieg, który pozwolił na zrekonstruowanie uniwersalnych (modelowych) cech aktywizmu sędziowskiego i ocenę działalności orzeczniczej sądów konstytucyjnych w oparciu o obiektywne (oderwane od konkretnego systemu) kryteria. W mojej ocenie jest to rozwiązanie, które umożliwiło porównanie działalności sądów funkcjonujących w bardzo różniących się systemach prawnych i społecznych. Równocześnie w pewnej mierze wymusiło ono na autorach pominięcie dorobku nauki pra- 
wa konstytucyjnego w powyższej materii, który ukształtował się w Polsce i w pozostałych opisanych państwach. Autorzy uczynili w tej kwestii wyjątek w stosunku do USA i stosukowo szczegółowo opisali poglądy naukowe dotyczące aktywizmu sędziowskiego i przyczyn jego powstania. W stosunku do pozostałych państw rozważania autorów sprowadzają się głównie do przedstawienia bogatego orzecznictwa oraz jego oceny w świetle przyjętej przez siebie definicji aktywizmu.

W mojej ocenie w opracowaniu brakuje mimo wszystko szerszego odniesienia aktywizmu sędziowskiego do podstaw prawnych działalności orzeczniczej poszczególnych sądów konstytucyjnych i oceny tych relacji. Równocześnie akceptuję fakt, iż nie taki cel postawili sobie autorzy recenzowanego opracowania. Ponadto, takie odniesienia są szeroko komentowanie i opisywane w doktrynach poszczególnych państw. Założeniem książki nie było zrelacjonowanie poglądów dotyczących zjawiska aktywizmu sędziowskiego, które przedstawiane są w naukach prawnych w Polsce i w innych państwach.

Istotę analiz zawartych w opracowaniu stanowią wyselekcjonowane orzeczenia sądów konstytucyjnych w poszczególnych państwach, które stanowią przejaw aktywizmu sędziowskiego. Na ich podstawie autorzy przedstawiają ewolucję zadań i kompetencji organów władzy sądowniczej. Ewolucja ta stanowi między innymi efekt działalności judykacyjnej tych podmiotów. Autorzy, z nielicznymi wyjątkami, nie wskazują przyczyn owych zmian. W szczególności autorzy nie czynią dystynkcji, czy owa ewolucja funkcji była skutkiem przemian społecznych, ustrojowych czy zmian przepisów prawa regulujących działalność organów władzy publicznej. Autorzy przyjęli założenie, iż każda zmiana linii orzeczniczej, wykładni przepisów prawa, rozszerzenia kompetencji, koncepcji orzekania itp. jest przejawem aktywizmu sędziowskiego. W mojej ocenie stanowi to pewne uproszczenie tego problemu. Immanentną cechą funkcjonowania organów władzy, w szczególności sądowniczej, jest ewolucja ich działalności. Dotyczy to zarówno sądów konstytucyjnych, którym obecnie przypisuje się cechę aktywizmu, jak również sądów postrzeganych w nauce jako pasywne (powściągliwe). Ewolucja działalności organów władzy sądowniczej wcale nie musi być przejawem aktywizmu sędziowskiego i może wynikać z innych przyczyn. Funkcjonowanie sądów i trybunałów pozostaje w ścisłym związku z dynamiką przemian społecznych. Pochodną tych przemian są zmiany postaw społecznych, 
moralności i prawa. W konsekwencji zmiany w judykaturze mogą wynikać nie z aktywistycznej postawy sędziów, tylko mieć charakter ewolucyjny, dopasowawczy, będący naturalną konsekwencją dynamiki przemian społecznych i podążający za nią. Ponadto, ewolucja kierunków orzekania może być efektem zmian w składach orzekających, na co nie bez słuszności zwracają również uwagę autorzy opracowania. Zmiany w judykaturze nie są wówczas efektem jakiejś ekstraordynaryjnej aktywności sądów, stanowią tylko przejaw naturalnej ewolucji działalności organów władzy sądowniczej będącej następstwem upływu czasu.

Uważam, że opracowanie naukowe Aktywizm sędziowski we współczesnych państwach demokratycznych stanowi bardzo cenną pozycję naukową. Autorzy postawili przed sobą niezmiernie poważny cel naukowy i w pełni go zrealizowali. Równocześnie pozycja ta stanowi istotny wkład w badania nad aktywistyczną i pasywistyczną aktywnością organów władzy sądowniczej. Jest ona istotnym przyczynkiem i punktem wyjścia dla dalszych analiz naukowych zarówno w płaszczyźnie komparatystycznego badania orzecznictwa sądów konstytucyjnych $w$ innych państwach, jak również polskiego Trybunału Konstytucyjnego. Praca stanowi spójny i logiczny wywód oraz niewątpliwie wypełnia lukę w polskiej literaturze naukowej. Dotychczasowe prace $\mathrm{z}$ tej dziedziny miały charakter fragmentaryczny, wypadkowy, nie traktowały powyższej problematyki w sposób kompleksowy i w zasadniczej mierze skupiały się na działalności organów władzy sądowniczej w Polsce. Autorzy opatrzyli swoje rozważania cennymi i ciekawymi uwagami historycznoporównawczymi, bogatą literaturą oraz licznymi orzeczeniami organów władzy sądowniczej. Opracowanie te niewątpliwie jest godne uwagi i polecenia.

Marcin Dąbrowski Uniwersytet Warmińsko-Mazurski w Olsztynie 